\title{
Impact of Internet Use on Economic Activities of West Sumatra
}

\author{
Alpon Satrianto ${ }^{1}$, Marwan $^{2}$, Halkadri Fitra ${ }^{3}$, Muhammad Kenzu Satrio ${ }^{4}$, Budi Sasongko ${ }^{5}$ \\ ${ }^{1-3}$ Economic Faculty Universitas Negeri Padang, $\triangle$ alpon.unp@gmail.com \\ ${ }^{4}$ Sumatera Barat Central Bureau of Statistics, $\triangle$ mkanzu@bps.go.id \\ ${ }^{5}$ STIEKN Jaya Negara, $\bowtie$ bud_ssk@yahoo.com
}

\begin{abstract}
This study aims to analyze the impact of internet usage on regional economic activities in West Sumatra. In particular, this study analyzes the impact of internet use on economic growth, consumption, investment and net exports of West Sumatra. This type of research is descriptive and associative research. The data in this study is in the form of panel data consisting of 19 districts / cities in West Sumatra from 2016-2018. The data analysis technique uses the Vector Autoregressive Panel (PVAR). The results of this study conclude that the use of the internet has a significant effect on economic growth, consumption, investment and net exports in both one and two previous periods. The use of the internet has the greatest impact in the short term on consumption activities in West Sumatra, while the use of the internet has the smallest impact in the short term on economic growth activities in West Sumatra. In the long run, the use of the internet has the greatest impact on economic growth in West Sumatra.
\end{abstract}

Keywords:

Internet, Economic Activity, PVAR

Article Received: 18 October 2020, Revised: 3 November 2020, Accepted: 24 December 2020

\section{Introduction}

One of the characteristics of the Industrial Revolution Era 4.0 is the massive use of the internet in various aspects of human life in the world today [1-3]. Hootsuite data records that the population of the earth connected to the internet in 2018 reached 4 billion people compared to 2014 which reached 2.4 billion people [4]. This figure shows that the internet penetration rate has reached $52.96 \%$ of the total world population. Indonesia is in 9 th position in the world based on the population of internet users in 2018.

Not apart from the world phenomenon, an increase in internet users is also seen in West Sumatra Province. Data from the West Sumatra Central Statistics Agency (BPS) shows that from 2016-2018 there has been an increase in the percentage of internet users from $25.06 \%$ to $36.49 \%$ (data on internet users has only been calculated by BPS West Sumatra since 2016). This condition can be seen in Figure 1 [5].

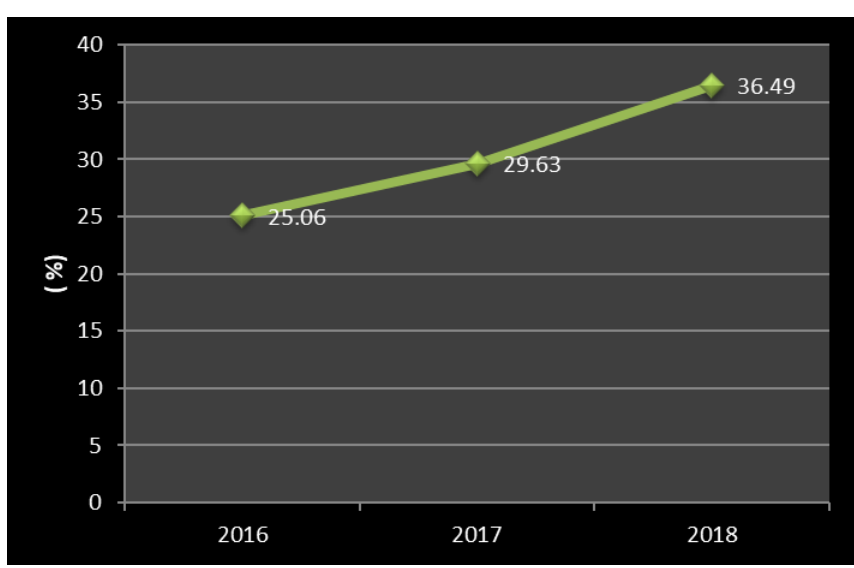

Figure 1: Percentage of Internet Users in West Sumatra from 2016-2018

Source: BPS West Sumatra

The current massive use of the internet has had an impact on the economic activities of the world's population. Many researchers have previously stated that the use of the internet has a positive impact on a country's economic growth, consumption, investment and net exports. Some of these studies in 207 countries in the world found that an increase in internet use by $1 \%$ had an impact on increasing economic growth by $0.057 \%$ [6-11]. Several other studies have found that a $1 \%$ increase 
in internet usage has an effect on consumption of $0.03 \%$, investment of $0.018 \%$ and net exports of $0.014 \%$. [11-21].

However, all these studies only analyze the impact or influence of internet use partially on regional economic activities such as economic growth, consumption alone, investment only and net exports only with the same analysis model, namely Ordinary Least Square (OLS). Based on this and in order to continue research on PNBP UNP funding in the previous year, the contribution of this research is to develop previous studies by analyzing the impact of internet use on regional economic activities in West Sumatra as a whole and not in isolation. This is done because research on internet activity in West Sumatra is still relatively new because data on internet usage was only published by BPS in 2016. The approach used is different, namely the Vector Autoregressive Panel / Vector Error Correction Model (PVAR / PVECM). This method is used because it can see how much and how long the impact of changes in one variable is responded to by other variables as a whole in a system of equations.

\section{Theoretical Framework}

The Solow model shows that sustainable economic growth can come from advances in technology. This Solow model has explained the technology variable as an exogenous variable, but the determinants of technology have not been explained in more detail. Then, the development of economic growth thinking after the Solow model has attempted to make technology variables as endogenous variables [21-22].

This theory explains how the levels of saving and investment, population growth and technological progress affect the level of output of an economy and its growth over time. In this theory, technological developments are assumed to be exogenous variables. The relationship between output, capital and labor can be written in the form of a function as follows:

$$
y=f(k)
$$

From equation 1 , it can be seen that output per worker (y) is a function of the capital stock per worker. In accordance with the production function that applies the law of deminishing return, where at the initial production point, the additional capital per worker will increase the output per worker more, but at a certain point the increase in the capital stock per worker will not increase the output per worker and will even increase the output per worker. could reduce output per worker. While the investment function is written as follows:

$$
i=s f(k)
$$

In this equation, the investment rate per worker is a function of the capital stock per worker. The capital stock itself is influenced by the amount of investment and depreciation where investment will increase the capital stock and depreciation will reduce it.

$$
\Delta k=i-\gamma k t
$$

$\gamma$ is the depreciation portion of the capital stock. A high saving rate will have an effect on increasing the capital stock and will increase income so that it will lead to rapid economic growth. However, in a certain period of time, economic growth will experience a slowdown if it has reached the so-called steady-state level of capital. This condition occurs when investment equals depreciation.

Apart from the saving rate, growth is also influenced by population growth. Population growth can better explain sustainable economic growth. Population increases the number of labor and by itself will reduce the capital stock per worker. The population growth rate and the depreciation rate together will reduce the capital stock. The effect of population growth can be written mathematically as follows:

$$
\Delta k=s f(k)-(\gamma+n) k t
$$


where $\mathrm{n}$ is the rate of population growth. In this theory it predicts that countries with high population growth will have low output per capita. Technological progress in Solow theory is considered an exogenous factor. In the next formulation the production function is:

$$
Y=f(K, L, E)
$$

where $\mathrm{E}$ is labor efficiency. Furthermore, $\mathrm{y}$ is $\mathrm{Y} / \mathrm{LE}$ where LE shows the number of effective workers. The effect of technological advances on changes in capital can be formulated as follows:

$$
\Delta k=s f(k)-(\gamma+n+g) k t
$$

where $\mathrm{g}$ describes technological progress through labor efficiency. The impact of technological advances can lead to sustainable economic growth by optimizing the efficiency of a growing workforce.

So, according to Solow's theory, there are several things that can be done to spur economic growth. In addition to savings and capital accumulation, technological advances can increase income per worker so that providing opportunities to innovate in the private sector will have a major impact on economic growth.

One of the factors that can be seen from technological advances is the accessibility of internet use. The use of the internet will be able to improve the production process effectively and efficiently. The increased production process will later have an impact on increasing economic growth [9-15].

Apart from economic growth, the use of the internet has an impact on other economic activities such as consumption, investment and net exports. One of the impacts of internet use on consumption, investment and net export activities can be seen from e-commerce activities. E-commerce or online business is increasingly advanced and intensive. This is due to the development of internet technology and changes in the behavior of economic actors. Easy internet access either through wifi or gadget devices makes it easier for people to access information about a product or service they are looking for coupled with the incessant promotions carried out by e-commerce companies in offering goods and services by offering various kinds of facilities for the community [16-18].

The ease of doing transactions via the internet has changed people's consumption patterns. Nowadays people are becoming more consumptive because information on the latest products can be known by consumers quickly through the internet media they have. In the end, this condition has an impact on increasing public consumption activities. This increase in public consumption patterns also has an impact on the emergence of investment activities such as the number of new businesses emerging both at the rural and urban levels. With the conveniences created by using the internet, trading activities between regions and between countries are inevitable. With the use of the internet, export transactions between regions and countries will become easier. Because information about a product, price, quality, design can be identified by consumers quickly [19-20]. Therefore the use of the internet has had many impacts on world economic activities such as production, consumption, investment and net exports.

\section{Method}

The data in this study are secondary data sourced from the Central Statistics Agency (BPS) of West Sumatra Province. This research variable data is in the form of panel data consisting of data on internet use, economic growth, consumption, investment and net exports in 19 districts / cities from 2016-2018.

The data analysis technique in this study used the Vector Autoregressive Panel / Vector Error Correction Model (PVAR / VECM). The form of the PVAR / VECM model in this study is as follows: 


$$
\begin{aligned}
& P I_{t}=\alpha_{1 i}+\sum_{i=1}^{n} \beta_{1 i} P I_{t-i}+\sum_{i=1}^{n} \theta_{1 i} P E_{t-i}+\sum_{i=1}^{n} \lambda_{1 i} K O_{t-i}+\sum_{i=1}^{n} \emptyset_{1 i} I V+\sum_{i=1}^{n} \delta_{1 i} N E_{t-i}+\varepsilon_{1 t} \\
& P E_{t}=\alpha_{2 i}+\sum_{i=1}^{n} \beta_{2 i} P I_{t-i}+\sum_{i=1}^{n} \theta_{2 i} P E_{t-i}+\sum_{i=1}^{n} \lambda_{2 i} K O_{t-i}+\sum_{i=1}^{n} \emptyset_{2 i} I V+\sum_{i=1}^{n} \delta_{2 i} N E_{t-i}+\varepsilon_{2 t} \\
& K O_{t}=\alpha_{3 i}+\sum_{i=1}^{n} \beta_{3 i} P I_{t-i}+\sum_{i=1}^{n} \theta_{3 i} P E_{t-i}+\sum_{i=1}^{n} \lambda_{3 i} K O_{t-i}+\sum_{i=1}^{n} \emptyset_{3 i} I V+\sum_{i=1}^{n} \delta_{3 i} N E_{t-i}+\varepsilon_{3 t} \\
& I V_{t}=\alpha_{4 i}+\sum_{i=1}^{n} \beta_{4 i} P I_{t-i}+\sum_{i=1}^{n} \theta_{4 i} P E_{t-i}+\sum_{i=1}^{n} \lambda_{4 i} K O_{t-i}+\sum_{i=1}^{n} \emptyset_{4 i} I V+\sum_{i=1}^{n} \delta_{4 i} N E_{t-i}+\varepsilon_{4 t} \\
& N E_{t}=\alpha_{5 i}+\sum_{i=1}^{n} \beta_{5 i} I_{t-i}+\sum_{i=1}^{n} \theta_{5 i} P E_{t-i}+\sum_{i=1}^{n} \lambda_{5 i} K O_{t-i}+\sum_{i=1}^{n} \emptyset_{5 i} I V+\sum_{i=1}^{n} \delta_{5 i} N E_{t-i}+\varepsilon_{5 t}
\end{aligned}
$$

Where,

$$
\begin{aligned}
\mathrm{PI} & =\text { Internet usage } \\
\mathrm{PE} & =\text { Economic Growth } \\
\mathrm{KO} & =\text { Consumption } \\
\mathrm{IV} & =\text { Investment } \\
\mathrm{NE} & =\text { Net exports }
\end{aligned}
$$

Before estimating the PVAR / VECM model, several tests were carried out including a) Stationary Test, b) Optimal Lag Test, c) PVAR / VECM Stability Test, d) Causality Test, e) Cointegration Test, f) Impulse Response Function (IRF) ) and g) Test Forecast Error Variance Decomposition (FEVD).

To analyze the impact of internet use on regional economic activities of West Sumatra, it can be analyzed using the IRF and FEVD approaches. Based on the IRF analysis, it will be seen the response given by regional economic activities due to the shock of internet use. Meanwhile, from the FEVD analysis, it will be seen how big the impact of internet use is on regional economic activity from the shock contribution given by internet use to economic growth, consumption, investment and net exports.

\section{Result}

\section{1) Stationary Test}

The method used to determine whether the variables in this study indicated stationary or not in the study were using the Dickey-Fuller (DF) unit root test. This test is named because it was developed by David Dickey and Wayne Fuller. A variable data is said to be stationary (H0 is rejected or Ha is accepted) if the statistical test value is smaller than the critical value or at the same time the variable probability value is smaller than $\alpha=$ 0.05 . Conversely, a variable data is said to be nonstationary (H0 is accepted or $\mathrm{Ha}$ is rejected) if the statistical test value is greater than the critical value or at the same time the variable probability value is greater than $\alpha=0.05$.(Nachrowi, 2006). However, if a variable data is categorized as non-stationary data, then the solution that can be done is with nonstationary process differences.

Table 1: Results of Stationary Test of Internet Usage Variables, Economic Growth, Consumption, Investment, and Net Exports of West Sumatra at Level 


\begin{tabular}{|l|c|l|}
\hline & Probability & \\
\hline Internet Use (PI) & 0.0000 & Stationary \\
\hline Economic Growth (PE) & 0.0000 & Stationary \\
\hline Consumption (KO) & 0.0007 & Stationary \\
\hline Investment (IV) & 0.0115 & Stationary \\
\hline Net Exports (NE) & 0.0212 & Stationary \\
\hline
\end{tabular}

Table 6.9 shows the results of the stationary test on the variables of internet use, economic growth and consumption at the level. From the table, it can be seen that the probability valueLevin, Lin \& Chu $\mathrm{t} *$ all variables namely the use of the internet for economic growth, consumption, investment and net exports at a level less than 0.05. Because all the variables in this study can be said to be average, variance and autocovariance are constant over time (for different lags the value is the same, it doesn't matter where to start measuring).

\section{2) Optimal Lag Test}

Selection of the optimal lag length is crucial in the VAR / VECM system because selecting the optimal lag length is useful for overcoming the impact of autocorrelation in the VAR / VECM system. Selection of the optimal lag length is also useful for showing how long a variable responds to other variables. (Ekananda, 2016).

To determine the optimal lag length criteria, several criteria can be used, including: Likelihood Ratio (LR), Final Prediction Error (FPE), Akaike Information Criteria (AIC), Schwarz Information Criterion (SIC), and Hannan Quinn. Information Criterion (HQ). Of the several criteria for determining the optimal lag, the criteria chosen in this study is the AIC method. The AIC method is used because in general, many studies use this method. Actually all criteria can be used as long as they are consistent in their use. The smallest AIC value will be marked with an asterisk.

\section{Table 2: Results of the Optimal Lag Test Model of the Impact of Internet Use on Regional Economic} Activities of West Sumatra

\begin{tabular}{ccccccc}
\hline \hline Lag & LogL & LR & FPE & AIC & SC & HQ \\
\hline \hline 0 & -371.3513 & NA & 275,5139 & 19,80796 & 20.02343 & 19.88463 \\
1 & -277.8746 & 157.4344 & 7,597837 & 16.20393 & $17.49676 *$ & 16.66391 \\
2 & -243.2831 & $49.15634 *$ & $4.927871 *$ & $15,69911 *$ & 18.06930 & $16.54241 *$ \\
\hline \hline
\end{tabular}

Table 2 shows the optimal lag test results for a model of the impact of internet use on regional economic activity in West Sumatra. From the table, it can be seen that the smallest AIC value (marked with an asterisk) is in lag 2 . Therefore, the optimal lag chosen in this study is lag 2 because it provides the smallest AIC value.

\section{3) Stability Test}

The stability of the VAR / VECM system can be seen from the inverse roots value of the AR polynomial characteristics or the modulus value in the AR-nominal table. Stability test is done by calculating the roots of the polynomial function, known as the roots of characteristic polynomial. A VAR / VECM system is categorized as stable if all of its AR-roots modulus values are below 1 . Whereas when all AR-roots modulus values are below 1, the VAR / VEMC system is categorized as unstable. A stable VAR / VECM system will produce valid IRF and FEVD analyzes. However, 
on the other hand an unstable VAR / VECM system will result in an invalid IRF and FEVD analysis.

Table 3 shows the results of the VAR / VECM stability test for this model. The table shows that all modulus values are below 1 . Thus, it can be said that the VAR / VECM system in this model is a stable VAR / VECM. A stable VAR / VECM will result in a valid or precise IRF and FEVD analysis.

Table 3: Results of the VAR / VECM Stability Test Model of the Impact of Internet Use on Regional Economic Activities of West Sumatra

\begin{tabular}{ll}
\hline \hline Root & Modulus \\
\hline \hline$-0.351988-0.462748 \mathrm{i}$ & 0.581404 \\
$-0.351988+0.462748 \mathrm{i}$ & 0.581404 \\
-0.235890 & 0.235890 \\
$0.056258-0.158158 \mathrm{i}$ & 0.167866 \\
$0.056258+0.158158 \mathrm{i}$ & 0.167866 \\
\hline \hline
\end{tabular}

\section{4) Causality Test}

The causality test in this study used the Granger Causality test. In essence, this test can indicate whether a variable has a two-way relationship, or only one direction. If the probability value is small than $\alpha=0.05$ (t-statistic is greater than t-table) then Ho is rejected or $\mathrm{Ha}$ is accepted, which means that the endogenous variable 1 affects endogenous variables 2 .On the other hand, if the probability value is small than $\alpha$ $=0.05$ ( $\mathrm{t}$-statistic is greater than $\mathrm{t}$-table) then Ho is rejected or $\mathrm{Ha}$ is accepted, which means that endogenous variable 2 affects endogenous variables 1. Based on this, it can be said that endogenous variables 1 and 2 have a two-way relationship or causality.

Table 5: Result of Causality Test Model Impact of Internet Use on Regional Economic Activities of West Sumatra

\begin{tabular}{lccc}
\hline \hline & & F- \\
Null Hypothesis: & Obs & Statistic & Prob. \\
\hline \hline PE does not Granger Cause PI & 38 & 2,05032 & 0.1448 \\
PI does not Granger Cause PE & & 2.81016 & 0.0746 \\
\hline \hline KO does not Granger Cause PI & 38 & 0.58513 & 0.5627 \\
PI does not Granger Cause KO & & 0.29893 & 0.7436 \\
\hline \hline IV does not Granger Cause PI & 38 & 2.89769 & 0.0693 \\
PI does not Granger Cause IV & & 1.22792 & 0.3059 \\
\hline \hline NE does not Granger Cause PI & 38 & 4.12051 & 0.0253 \\
PI does not Granger Cause NE & & 7,84872 & 0.0016 \\
\hline \hline KO does not Granger Cause PE & 38 & 0.27414 & 0.7619 \\
PE does not Granger Cause KO & & 6.22102 & 0.0051 \\
\hline \hline
\end{tabular}




\begin{tabular}{lccc} 
IV does not Granger Cause PE & 38 & 0.57659 & 0.5674 \\
PE does not Granger Cause IV & & 7,15075 & 0.0026 \\
\hline \hline NE does not Granger Cause PE & \multirow{2}{*}{38} & $\begin{array}{l}0.07212 \\
\text { PE does not Granger Cause NE }\end{array}$ & 0.9306 \\
\hline \hline IV does not Granger Cause KO & \multirow{2}{*}{38} & 3.72239 & 0.0349 \\
KO does not Granger Cause IV & & 4.15067 & 0.0247 \\
\hline \hline NE does not Granger Cause KO & \multirow{2}{*}{38} & 0.89662 & 0.4177 \\
KO does not Granger Cause NE & & 1.61367 & 0.2145 \\
\hline \hline NE does not Granger Cause IV & \multirow{2}{*}{38} & 1.15959 & 0.3261 \\
IV does not Granger Cause NE & & 0.24359 & 0.7852 \\
\hline \hline
\end{tabular}

Table 5 shows the results of the causality test in this model. From the table, it can be seen that the variables that have a two-way relationship or causality are Net Exports with Internet Use and Investment with Consumption. This can be seen from the probability value of the NE on the PI smaller than 0.05 , and the probability value of the PI against the NE is also smaller than 0.05. Likewise with the investment variable with consumption, the probability value IV for $\mathrm{KO}$ is smaller than 0.05 , and the probability value for $\mathrm{KO}$ to IV is also smaller than 0.05. Meanwhile, the relationship between other variables does not indicate a two-way relationship. Although many of the relationships between these variables do not show a two-way relationship, testing of this model can still be continued.

\section{5) Cointegration Test}

The cointegration test in this study uses the Kao cointegration test. If the probability value of the cointegration Kao ADF is greater than zero then the model is said to be a non-cointegrated model. Meanwhile, if the cointegration Kao ADF probability value is smaller than zero then the model is said to be a non-cointegrated model. If the model is co-integrated, the analysis used is the VECM Panel, but if the model is not co-integrated, the analysis used is the VAR Panel.

\section{Table 6: Cointegration Test Results Model Impact of Internet Use on Regional Economic Activities of West Sumatra}

\begin{tabular}{lcc}
\hline \hline \multirow{2}{*}{ ADF } & t-Statistic & Prob. \\
\cline { 2 - 3 } \multicolumn{1}{c}{ Residual variance } & -1.268605 & 0.7235 \\
HAC variance & 24,47869 & \\
\hline \hline
\end{tabular}

Table 6 shows the results of the Kao cointegration test on the model of the impact of internet use on regional economic activity in West Sumatra. The table shows that the ADF probability value is greater than 0.05. Because the ADF probability value is greater than 0.05 , it can be stated that this model is not cointegrated. Thus, the model of the impact of internet use on regional economic activities in West Sumatra can be estimated using the VAR model (Panel VAR). 
The discussion of the VAR estimation coefficient here focuses on the effect of internet use on economic growth, consumption, investment and net exports. Meanwhile, the estimated coefficient of the effect of endogenous variables on other endogenous variables is not discussed here because the focus of the study in this study is the impact of internet use on regional economic activities in West Sumatra.

Table 7 shows the VAR estimation results of the impact of internet use on economic growth, consumption, investment and net exports. In the table, it can be seen that the effect of internet use in the previous period had a significant negative effect on economic growth and net exports. This condition can be seen from the t-count value of economic growth and net export, respectively -4.34 and -3.19 which are smaller than the t-table value of -1.99 (this value is obtained from $\mathrm{df}=76-10=$ 66 with $\alpha=0.05$ ). Meanwhile, internet usage in the previous period had a significant positive effect on consumption and investment. This condition can be seen from the t-count value of consumption and investment, respectively 3.70 and 3.12 , which is greater than the t-table value of 1.99 .

\section{Table 7: VAR Estimation Results of the Impact of Internet Use on Regional Economic Activities of West Sumatra}

\begin{tabular}{ccccc}
\hline \hline & PE & KO & IV & NE \\
\hline \hline PI (-1) & -0.634984 & 0.419602 & 0.741155 & -0.355630 \\
& $(0.14626)$ & $(0.113319)$ & $(0.23736)$ & $(0.111477)$ \\
& {$[-4.34160]$} & {$[3.702830]$} & {$[3.12244]$} & {$[-3.190163]$} \\
& & & & \\
PI (-2) & 0.072174 & -0.510492 & -0.467490 & 1,899968 \\
& $(0.021651)$ & $(0.12838)$ & $(0.14185)$ & $(0.84371)$ \\
& {$[3.333518]$} & {$[-3.97642]$} & {$[-3.29568]$} & {$[2.25193]$}
\end{tabular}

In the two previous periods, internet usage had a significant positive impact on economic growth and net exports. This can be seen from the t-count value of economic growth and net export, respectively 3.33 and 2.25 , which is greater than the t-table value of 1.99. Meanwhile, internet usage in the previous two periods had a significant negative effect on consumption and investment. This can be seen from the t-count value of consumption and investment, respectively -3.97 and -3.29 which are smaller than the t-table value of -1.99 .

\section{7) Impulse Response Function (IRF)}

IRF used to see the effect of shock from one variable on other variables. A shock to the endogenous variable will affect the variable itself and will spread to other endogenous variables. IRF provides the direction of the relationship between the magnitude of the influence between endogenous variables. Estimates made for this IRF are focused on the response of a variable to changes in one standard deviation from the variable itself or from other variables contained in the VAR model.

Figure 2 shows the response to economic growth as a result of the shock of internet use. There is a shock from the use of the internet that the economic growth initially tends to flatten or there is no response. However, after the 7th period, the economic growth showed a response due to the shock of internet use, even though the response was very unresponsive. In period 9, the response to economic growth tends to move away from the balance line. Therefore, the response to economic growth due to the shock of internet use is 
permanent in the long run because the economic growth response line moves away from the balance line.

Response of PE to Cholesky

One S.D. PI Innovation

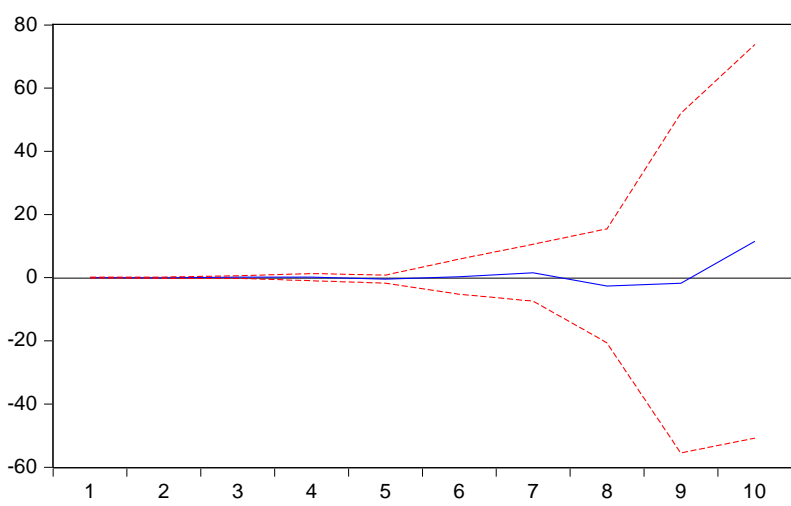

Figure 2: IRF Results Response to Economic Growth Due to Shock in Internet Use

Figure 3 shows the response to changes in consumption resulting from the shock of internet use. The shock of using the internet on the response to consumption was initially not responded to by consumption or the response tended to flatten out. Then after the 8th period, the consumption response slightly decreases from the balance line and returns to the balance line in period 10 . This means that the consumption response resulting from the shock of internet use is not permanent in the long run because the consumption response is towards the balance line. This situation means that the use of the internet does not have a permanent impact on consumption.

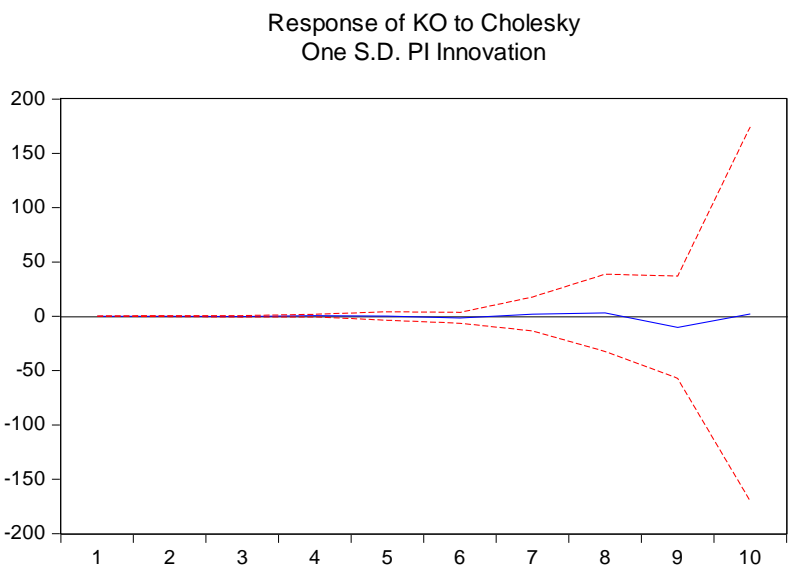

Figure 3: Consumption Response IRF Results Due to Internet Use Shock
Figure 4 shows the investment response resulting from the shock of internet use. Investments did not initially respond to the shock of internet use. This can be seen from the investment impulse line which flattened up to the 8th period. It was only in the 9th period that the shock of internet use was responded to by an increase in investment. However, the response tends to be short so that in the 10th period the investment response returns to the balance line. With the meaning of the word that the shock of internet use on investment is also not permanent in the long term or internet use does not have a permanent impact on investment.

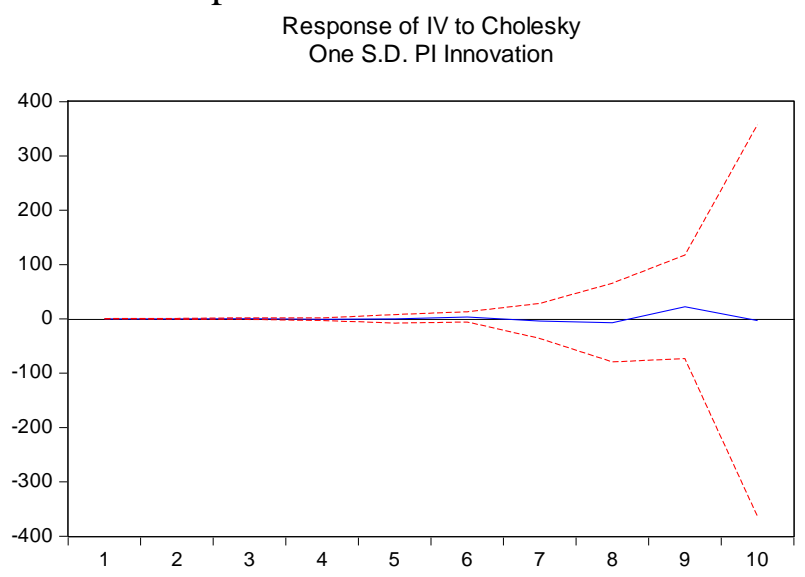

Figure 4: IRF Investment Response Results Due to Shock in Internet Use

Figure 5 shows the net export response due to the shock of internet use. Similar to economic growth, consumption and investment, net exports respond to internet usage shocks flatly or with no response. However, it was only in the 9th period that net exports gave a slight increase in response to the shock of internet use. In fact, it can be said that there is almost no real response. Because after period 9, or until period 10, the net export response tends to return to the balance line. This indicates that the shock of internet use on net exports is also not permanent in the long term. Or in other words, the use of the internet does not have a permanent impact on net exports. 


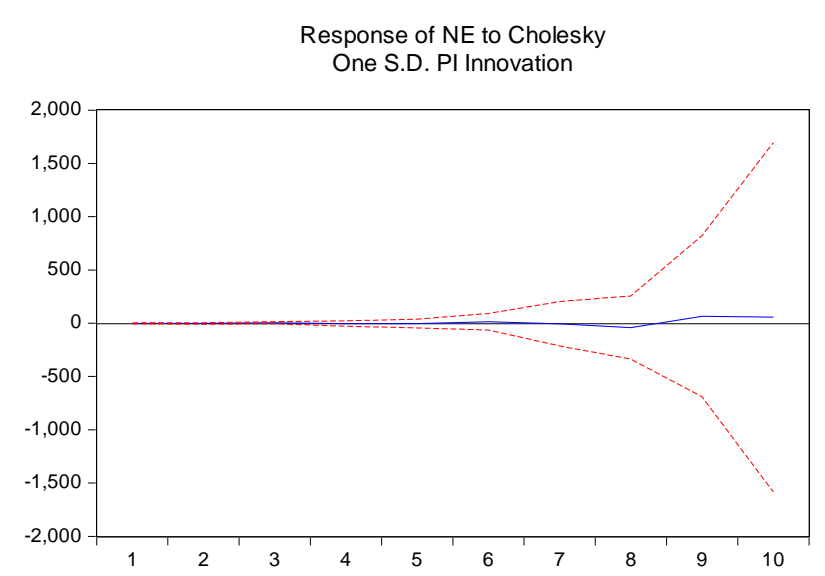

Figure 5: IRF Results Net Export Response Due to Internet Use Shock

\section{8) Forecast Error Variance Decomposition (FEVD)}

Forecast error variance decomposition (FEVD) is an analysis that provides information related to the dynamic relationship between endogenous variables and endogenous variables in the VAR / VECM dynamic system. FEVD is a shock from the factors that affect the variability (fluctuation) of certain variables against other variables which is carried out orthogonally. FEVD is carried out to see what percentage of the role of each shock (shock) is on the variability of certain variables or to examine the sources of fluctuation in certain variables. Thus it can be known with certainty the factors that affect the fluctuation of one variable against other variables. These factors constitute policy implications that play an important role in the stability of these variables.

Table 8 shows the results of the FEVD model of the impact of internet use on regional economic activities in West Sumatra. In the table, it can be seen that the variability of economic growth in the short term can be explained by the shock from internet use of $0.05 \%$ and in the long run by $3.36 \%$. The short-term consumption variability is explained by the internet usage shock of $2.70 \%$ and in the long term it decreases to $0.34 \%$. Meanwhile, the shock of internet use on investment variability in the short term was $2.33 \%$ and decreased in the long term to $0.34 \%$. Likewise, the shock of internet use on the variability of net exports in the short term was $1.63 \%$ and decreased to $0.38 \%$ in the long term.

From the FEVD results, it can be concluded that the use of the internet has the greatest impact in the short term, namely on consumption activities in West Sumatra. This can be seen from the value of the variability in consumption due to the shock of internet use, which is the largest among other West Sumatra economic activity variables, such as economic growth, investment and net exports. This is because in the short term internet use can make it easier for people to consume, such as internet quota usage, on-line shopping, e-commerce and others. Thus the effect of internet use is immediately felt in the short term on increased consumption. The smallest impact of internet use in the short term is seen in the economic growth variable. This situation is due to the use of the internet not directly having an impact on economic growth but through the variables of consumption, investment and net exports. That is why in the long term the shock of internet use has the greatest impact on the variability of economic growth. Meanwhile, the shock of internet use had quite a small impact on consumption, investment and net exports, even less than $1 \%$. 
Table 8: The results of the FEVD Model of the Impact of Internet Use on Regional Economic Activities of West Sumatra

\begin{tabular}{|c|c|c|c|c|c|c|c|}
\hline $\begin{array}{l}\text { Variance } \\
\text { Decomposition of } \\
\text { PE: } \\
\text { Period }\end{array}$ & PI & $\begin{array}{c}\text { Variance } \\
\text { Decomposition of } \\
\text { KO: } \\
\text { Period }\end{array}$ & PI & $\begin{array}{c}\text { Variance } \\
\text { Decomposition of } \\
\text { IV: } \\
\text { Period }\end{array}$ & PI & $\begin{array}{c}\text { Variance } \\
\text { Decomposition of } \\
\text { NE: } \\
\text { Period }\end{array}$ & PI \\
\hline 1 & 0.058122 & 1 & 2.701397 & 1 & 2.338405 & 1 & 1.631916 \\
\hline 2 & 0.800538 & 2 & 0.775709 & 2 & 0.176408 & 2 & 2,517578 \\
\hline 3 & 1.806211 & 3 & 0.451452 & 3 & 0.487935 & 3 & 4.441505 \\
\hline 4 & 0.558059 & 4 & 4.047577 & 4 & 2,560548 & 4 & 3.273546 \\
\hline 5 & 3.203011 & 5 & 0.413630 & 5 & 0.257346 & 5 & 0.974048 \\
\hline 6 & 0.450564 & 6 & 2.038710 & 6 & 2.359072 & 6 & 3.504332 \\
\hline 7 & 1.369215 & 7 & 1.118169 & 7 & 0.980888 & 7 & 0.448694 \\
\hline 8 & 1.901829 & 8 & 0.596897 & 8 & 0.594054 & 8 & 1.583020 \\
\hline 9 & 0.347660 & 9 & 3.424268 & 9 & 3.411885 & 9 & 1.648884 \\
\hline 10 & 3.362942 & 10 & 0.349994 & 10 & 0.340339 & 10 & 0.385981 \\
\hline
\end{tabular}




\section{Conclusion}

The results of this study conclude that the use of the internet has a significant effect on economic growth, consumption, investment and net exports in both one and two previous periods. The use of the internet has the greatest impact in the short term on consumption activities in West Sumatra, while the use of the internet has the smallest impact in the short term on economic growth activities in West Sumatra. In the long run, the use of the internet has the greatest impact on the economic growth of West Sumatra.

From the results of this study the suggestions put forward in this study are 1) The government needs to improve the quality and quantity of internet infrastructure, especially in West Sumatra because it is evident from this study that the use of the internet has an impact on regional economic activities. 2) The government needs to invite investors related to investment in Information and Communication Technology (ICT) because in this era of the 4.0 era this field can facilitate, facilitate and encourage regional economic activity. Even the countries that control this field will be able to determine the direction of world economic competition in the future. 3) The government and related elements need to prepare Human Resources who are experts in this field because in the future the direction of competition is already fully digitalized.

\section{References}

[1] Gubán, M., \& Kovács, G. 2017. Industry 4.0 Conception. Acta Technica Corviniensis-Bulletin of Engineering. Vol. 10. No. 1. Pp. 111-118.

[2] Botta, A., De Donato, W., Persico, V., \& Pescapé, A. 2016. Integration of Cloud Computing and Internet of Things: A Survey. Future Generation Computer Systems. Vol 56. No.2. Pp. 684-700.

[3] Hsu, C.-L., \& Lin, JC-C. 2016. An Empirical Examination of Consumer Adoption of Internet of Things Services: Network Externalities and Concern for
Information Privacy Perspectives.Computers in Human Behavior. Vol. 62. No.3. Pp. 516-527.

[4] Hootsuite. Digital 2020 Global Overview Report.https://wearesocial.com/blog/2020/ 01/digital-2020-3-8-billion-people-usesocial-media.

[5] Badan Pusat Statistik. 2019. Sumatera Barat Dalam Angka. Padang : Badan Pusat Statistik.

[6] Kenny, Charles. 2003. The Internet and Economic Growth in Less-developed Countries: A Case of Managing Expectations ?.Oxford Development Studies. Vol. 31. No. 1. Pp. 99-103.

[7] Choi, Changkyu\& Myung Hoon Yi. 2009.The Effect of the Internet on Economic Growth: Evidence From CrossCountrypanel Data. Economics Letters. Vol. 105.Pp. 39-41.

[8] Chu, Shin-Yang. 2013. Internet, Economic Growth and Recession. Modern Economy. Vol. 4. No. 2. Pp. 209-2013.

[9] Yasmeen, Rizwana \& Sadia Tufail. 2015. Impact of Internet Technology on Economic Growth in South Asia with Special Reference to Pakistan.Pakistan Journal of Social Sciences. Vol. 35. No. 2. Pp. 777-784.

[10] Edquist, Harald, Peter Goodridge \& Jonathan Haskel. 2019. The Internet of Things and Economic Growth in a Panel of Countries.Economics of Innovation and New Technology. Vol. 24.Pp. 1-23.

[11] Haftu, Girmay Giday. 2019. Information Communications Technology and Economic Growth in Sub-Saharan Africa: A Panel Data Approach.Telecommunications Policy. Vol. 42. Pp. 23-36.

[12] Bilgihan, A., Kandampully, J., \& Zhang, T. Christina. 2016. Towards a Unified Customer Experience in Online Shopping Environments: Antecedents and Outcomes. 
International Journal of Quality and Service

Sciences. Vol. 8. No. 1. Pp. 102-119.

[13] Wang, Yan \& Fen Hao. 2018. Does Internet Penetration Encourage Sustainable Consumption? A Cross-National Analysis.Sustainable Production and Consumption. Vol. 28. No. 2. Pp. 1-40.

[14] Füller, J., Mühlbacher, H., Matzler, K., \& Jawecki, G. 2009. Consumer Empowerment Through Internet-Based CoCreation. Journal of Management Information Systems. Vol. 26. No. 3. Pp. 71-102.

[15] Choi, Changkyu. 2003.Does the Internet Stimulate Inward Foreign Direct Investment ?. Journal of Policy Modeling. Vol. 24. No. 4. Pp. 319-326.

[16] In Lee \& Kyoochun Lee. 2015. The Internet of Things (IoT): Applications, Investments, and Challenges for Enterprises.Business Horizons. Vol. 58. No. 4. Pp. 431-440.

[17] Clarke, George RG \& Scott J. Wallsten. 2004. Has the Internet Increased Trade? Evidence from Industrial and Developing Countries.Journal of Economic Perspectives Vol. 16.No. 3. pp. 153-170.

[18] Choi, Changkyu. 2010.The Effect of the Internet on Service Trade. Economics Letters. Vol. 109. pp. 102-104.

[19] Lin, Faqin. 2014. Estimating the Effect of the Internet on International Trade.The Journal of International Trade \& Economic Development. Vol. 27. No. 3. pp. 1-20.

[20] Yousefi, Ayoub. 2018. Estimating the Effect of the Internet on International Trade in Services. Journal of Business Theory and Practice. Vol. 6. No. 1. pp. 65-82.

[21] Satrianto, Alpon, Marwan, Halkadri Fitra, Muhammad Kenzu Satrio, \& Budi Sasongko. 2020. The Effect of Economic Factors and Characteristics of West Sumatra Society in Accessing The Internet. International Journal of Advanced Science and Technology. Vol. 29. No. 04. pp. 1071 $-1084$.
[22] Mankiw, Gregory N. 2010. Macroeconomics. New York: 41 Madison Avenue.

[23] Romer, David. 2018.Advanced Macroeconomics. McGraw-Hill. 